\title{
Expression and function of vasoactive intestinal peptide receptors in human lower esophageal sphincter
}

\author{
Tao Jia ${ }^{1}$, Ning Zhao ${ }^{2}$ \\ ${ }^{1}$ Department of Thoracic Surgery, Handan Central Hospital, Handan, China; ${ }^{2}$ The Eighth Department of General surgery, Handan Central \\ Hospital, Handan, China \\ Contributions: (I) Conception and design: T Jia; (II) Administrative support: N Zhao; (III) Provision of study materials or patients: N Zhao; (IV) \\ Collection and assembly of data: T Jia; (V) Data analysis and interpretation: T Jia; (VI) Manuscript writing: All authors; (VII) Final approval of \\ manuscript: All authors. \\ Correspondence to: Ning Zhao. Handan Central Hospital, 59 Congtai North Road, Handan 056008, China. Email: 598588965@qq.com.
}

\begin{abstract}
Background: Vasoactive intestinal peptide (VIP) is an important neurotransmitter involved in the modulation of gastrointestinal function through the stimulation of VIP receptors. However, the expression of VPAC1R, VPAC2R and PAC1R in the human Lower esophageal sphincter (LES) has not been fully clarified. Therefore, the purpose of this study is to explore the expression of these receptors in the human Lower esophageal sphincter, the responses of the Lower esophageal sphincter to Vasoactive intestinal peptide, and the role of Vasoactive intestinal peptide receptors in the responses.
\end{abstract}

Methods: Sling and clasp fiber samples of LES were acquired from patients undergoing subtotal esophagectomy, while circular muscle bundles from the esophagus and gastric fundus were used as control groups. Western blotting and RT-PCR technology were performed to determine the expression of the three VIP receptor subtypes. The isometric tension responses of the muscle sample strips to Ro25-1553 and PG99-465, and the effect of electrical field stimulation (EFS) on the sling and clasp fibers were studied.

Results: We found that VPAC2R messenger RNA (mRNA) and protein were expressed in the sling and clasp fibers of human LES. However, no VPAC1R or PAC1R mRNA and protein expressions were found in the LES samples. The sling and clasp fibers of the LES produced significant concentration-dependent relaxation following exposure to Ro25-1553 and EFS could induce them to produce frequency-dependent relaxation. Furthermore, the relaxation responses of the LES were inhibited by PG99-465 and induced by EFS and Ro25-1553.

Conclusions: VPAC2R, but not VPAC1R or PAC1R, is expressed by the human LES. The relaxation responses of the LES generated by the VIP receptor agonist Ro25-1553 and EFS could be inhibited by the selective VPAC2 receptor antagonist PG99-465. VPAC2R may be important for the generation of relaxation and functional regulation of the LES.

Keywords: Clasp fiber; sling fiber; vasoactive intestinal peptide receptor (VIP receptor); human; lower esophageal sphincter (LES)

Submitted Dec 15, 2020. Accepted for publication Mar 16, 2021.

doi: $10.21037 / \mathrm{apm}-21-193$

View this article at: http://dx.doi.org/10.21037/apm-21-193

\section{Introduction}

Vasoactive intestinal peptide (VIaP) functions via binding to corresponding VIP receptors distributed throughout human and animal tissues. VIP receptors are divided into three categories according to the nomenclature of the
International Union of Pharmacology (1): VIP receptor type 1 (VPAC1R), VIP receptor type 2 (VPAC2R), and pituitary adenylate cyclase-activating polypeptide type 1 receptor (PAC1R). These same receptors found in VIP are also found in pituitary adenylate cyclase-activating 


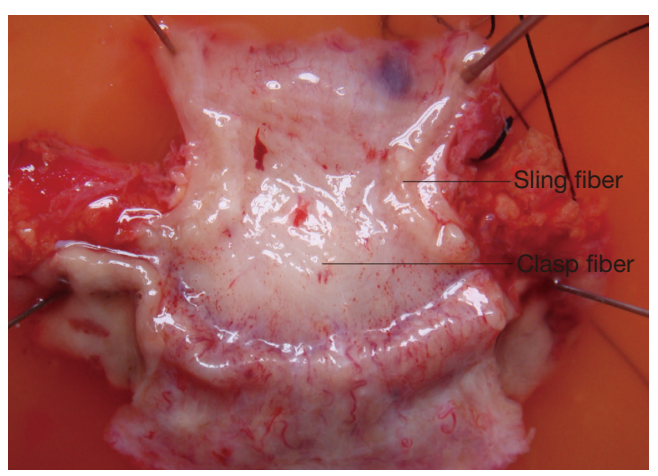

Figure 1 Sling and clasp fibers of the human LES. Specimens were dissected along the longitudinal line of the esophagus and the greater curvature of the stomach. The lower esophageal sphincter (LES) is a circular muscle bundle with obvious thickening at the junction of the lower esophagus and the proximal stomach. Clasp fibers of LES are located at the lesser curvature of the stomach, while sling fibers of LES are at the greater curvature of the stomach. LES, lower esophageal sphincter

peptide (PACAP). VPAC1R is predominantly distributed in peripheral tissues, such as the lung and small intestine and its expression is rarely observed in the encephalic regions of the central nervous system (CNS), except the deutocerebrum (2). VPAC2R has been shown to have a wider distribution than VPAC1R and is widely distributed in the CNS. Thus, VPAC2R is also known as the endocrine neuroreceptor (3). PACAP binds to PAC1R with a greater affinity than VIP (4), and messenger RNA (mRNA) encoding PAC1R is predominantly expressed in the CNS (5) and adrenal medulla (6).

Current studies on the regulatory mechanisms of the human lower esophageal sphincter (LES) have almost entirely focused on the roles of cholecystokinin (CCK) and muscarinic acetylcholine receptors $(7,8)$ and both have been shown to substantially contribute to the regulation of the LES. Previous studies of esophageal VIP and VIP receptor expression have largely been conducted on animals, which may limit their applicability to humans due to species differences. As a result, there is a lack of data regarding VIP receptors in the human LES. Therefore, the purpose of this study is to explore the expression of three VIP receptor subtypes in human LES by RT-PCR and Western blot technology. The responses of human LES to Ro25-1553, PG99-465, and electrical field stimulation (EFS) were also studied to determine the regulatory characteristics of VIP receptors in the human LES and to determine the biological characteristics of the latter. We present the following article in accordance with the MDAR reporting checklist (available at http://dx.doi.org/10.21037/apm-21-193).

\section{Methods}

\section{Patients and tissue}

The study was conducted in accordance with the Declaration of Helsinki (as revised in 2013). The study was approved by ethics board of Handan central hospital (No.: 20200122) and informed consent was taken from all the patients. Specimens, including sling fibers, clasp fibers, and circular strips of esophageal and gastric fundal muscle tissues were obtained from 40 patients undergoing subtotal resection with esophageal carcinoma at Handan Central Hospital. Included subjects consisted of 22 male and 18 female patients with an average age of 60 years (range, 55-72 years). Patients with a history of esophageal dyskinesia or other esophageal diseases associated with LES dysfunction were excluded. Specimens were resected and immediately placed in ice-cold Krebs solution and those found to have macroscopic evidence of malignancy were excluded from the study. Krebs solution consisted of the following ingredients: $\mathrm{MgSO} 41.2 \mathrm{mmol} / \mathrm{L}$, $\mathrm{NaH} 2 \mathrm{PO} 4.2 \mathrm{H} 2 \mathrm{O} 1.0 \mathrm{mmol} / \mathrm{L}, \mathrm{NaCl} 118.3 \mathrm{mmol} / \mathrm{L}$, $\mathrm{NaHCO} 325 \mathrm{mmol} / \mathrm{L}$, Glucose $11.1 \mathrm{mmol} / \mathrm{L}, \mathrm{KCl}$ $4.6 \mathrm{mmol} / \mathrm{L}$, and $\mathrm{CaCl} 22.5 \mathrm{mmol} / \mathrm{L}$.

Specimens were dissected along the longitudinal line of the esophagus and the greater curvature of the stomach, respectively. After rinsing with $37^{\circ} \mathrm{C}$ Krebs solution and inflated with $95 \% \mathrm{O}_{2}$ and $5 \% \mathrm{CO}_{2}$, the specimens were fixed so that the mucous membrane was placed upward and the original size was maintained. The mucosa and submucosa were then exfoliated sharply and sling fiber and clasp fibers were identified (Figure 1). Similar-sized (2-mm wide and 10-mm long) sling and clasp fiber muscle strips were made and placed into Krebs solution that had been constantly inflated with $5 \% \mathrm{CO}_{2}$ and $95 \% \mathrm{O}_{2}$ at $37{ }^{\circ} \mathrm{C}$ with the long axis of each muscle strip placed in the same direction as the muscle fiber. Circular strips of esophageal and gastric fundal muscle were prepared as control specimens. At the proximal and distal end of the gastroesophageal junction, the circular muscle bundles of the esophagus and fundus of stomach were taken, respectively. Specimens were carefully inspected for potential tumour involvement and discarded if evidence of malignancy was less than $5 \mathrm{~cm}$ from the proximal end of 
Table 1 Primer sequence and prospective result size

\begin{tabular}{llll}
\hline Gene & Gene bank login number & Primer pair sequence & Result size (bp) \\
\hline VPAC1 & NM_001251882 & 5'-CCACCACAAAACCCTGGAAAGAC-3', 5'-GGGACACCATCAACTCCTCACTG-3' & 297 \\
VPAC2 & NM_003382 & 5'-GACCCAACACCTTCAGTTACCACAA-3', 5'-TCTGCTGCAACAAGCTCATCCCT-3' & 382 \\
PAC1 & NM_001199635 & 5'-ATTTCGCTTGATCTCCGCTTGT-3', 5'-AGAACTGTCCACCATTACTCTGCG-3' & 213 \\
$\beta$-actin & NM-001101 & 5'-GTGGGGCGCCCAGGCACCA-3', 5'-CTCCTTAATGTCACGCACGATTC-3' & 540 \\
\hline
\end{tabular}

$\mathrm{Bp}$, base pair; indicating the length of primer.

the muscle was observed. Muscle strips were also examined microscopically to confirm the absence of malignancy. Before RNA and protein extraction, the isolated strips were frozen in liquid nitrogen and stored at $-80^{\circ} \mathrm{C}$.

\section{$R N A$ isolation and reverse transcription-polymerase chain reaction (RT-PCR)}

At a concentration of $100 \mathrm{mg} / \mathrm{mL}$, Trizol solution was added to the muscle fiber samples and homogenized and the tissue fluid then centrifuged at 12,000 rpm for $5 \mathrm{~min}$. The acid guanidine thiocyanate phenol chloroform extraction method was used to extract total RNA and agarose gel electrophoresis was used to identify whether the total RNA was intact. In the presence of $\mathrm{M}-\mathrm{MuLV}$, the first strand cDNA was synthesized. Reverse transcriptase was performed using $0.5 \mu \mathrm{g}$ oligo(dT) 18 and diethypyrocarbonate-treated water to a final volume of $11 \mu \mathrm{L}$ before incubation at $65^{\circ} \mathrm{C}$ for $5 \mathrm{~min}$ and subsequent cooling on ice. A $4 \mu \mathrm{L} 5 \times$ reaction buffer, $2 \mu \mathrm{L} 10 \mathrm{~mm} 4 \mathrm{dNTP}$ mixture, and 20 units of RNasin were then added to samples with diethypyrocarbonate-treated water to a final volume of $19 \mu \mathrm{L}$ before incubation at $37^{\circ} \mathrm{C}$ for $2 \mathrm{~min}$. Finally, $1 \mu \mathrm{L}$ $\mathrm{M}-\mathrm{MuLV}$ reverse transcriptase was added and incubated at $37^{\circ} \mathrm{C}$ for $50 \mathrm{~min}$ and the reaction was terminated at $70^{\circ} \mathrm{C}$ for $15 \mathrm{~min}$. At this time, the cDNA of the reaction product could be used for the next test.

PCR was used to amplify $2 \mu \mathrm{L}$ cDNA in a $20 \mu \mathrm{L}$ amplification system and primers were designed specifically against VIP receptor mRNA transcripts (Table 1 lists the primers used, Provided by Shanghai bioengineering company). The reaction volume of PCR consisted of PCR buffer, $2 \mathrm{mM} \mathrm{MgCl}$, $200 \mathrm{~mm}$ dNTPs, $0.1 \mathrm{~nm}$ primer, and 2 units of Taq DNA polymerase. Each VIP receptor has different amplification conditions and the following PCR protocol was used for VPAC1: denaturing at $94^{\circ} \mathrm{C}$ for $2 \mathrm{~min}$, denaturation at $94^{\circ} \mathrm{C}$ for 30 seconds, annealing at $58^{\circ} \mathrm{C}$ for 30 seconds, and extending for 30 seconds at $72{ }^{\circ} \mathrm{C}$ for a total of 35 cycles, and the reaction was terminated at $72{ }^{\circ} \mathrm{C}$ for $2 \mathrm{~min}$. For VPAC2 this involved denaturing at $94{ }^{\circ} \mathrm{C}$ for $2 \mathrm{~min}$, denaturation at $94{ }^{\circ} \mathrm{C}$ for 30 seconds, annealing at $60{ }^{\circ} \mathrm{C}$ for 30 seconds, and extending for 30 seconds at $72{ }^{\circ} \mathrm{C}$ for a total of 35 cycles, and the reaction was terminated at $72{ }^{\circ} \mathrm{C}$ for $2 \mathrm{~min}$. For PAC1 this saw denaturing at $94^{\circ} \mathrm{C}$ for $2 \mathrm{~min}$, denaturation at $94{ }^{\circ} \mathrm{C}$ for 30 seconds, annealing at $56^{\circ} \mathrm{C}$ for 30 seconds, and extending for 30 seconds at $72{ }^{\circ} \mathrm{C}$ for a total of 35 cycles, and the reaction was terminated at $72{ }^{\circ} \mathrm{C}$ for $2 \mathrm{~min}$. Finally, for $\beta$-actin, denaturing at $94{ }^{\circ} \mathrm{C}$ for $2 \mathrm{~min}$, denaturation at $94^{\circ} \mathrm{C}$ for 30 seconds, annealing at $56^{\circ} \mathrm{C}$ for 30 seconds, and extending for 30 seconds at $72^{\circ} \mathrm{C}$ for a total of 35 cycles, and the reaction was terminated at $72{ }^{\circ} \mathrm{C}$ for $2 \mathrm{~min}$. PCR amplification was performed using the system without substrate cDNA but only primers as negative control.

The products amplified by PCR were placed in $1.5 \%$ agarose gel and electrophoresis was observed. Bands of expected sizes were observed on electrophoresis for all analysed RT-PCR amplification products and units of integrated optical density (IOD) for electrophoresis gels were calculated with Gel-Pro software. VIP receptor mRNA expression values were expressed as the ratios of IOD values for each VIP receptor band to corresponding $\beta$-actin bands.

\section{Western blot analysis}

We placed $20 \mathrm{mg}$ of the prepared muscle samples in an EP tube respectively, and a 200 UL TBS solution was then added to the tube to wash the samples. The washed specimens were then homogenized and centrifuged, and the crude protein homogenate was denatured by boiling for 5 minutes, then separated on $10 \%$ polyacrylamide gel $(10 \mathrm{mg} / \mathrm{lane})$ and transferred to PVDF membrane by electrophoresis. The membrane was placed in $5 \%$ skimmed milk powder and sealed at room temperature for 2 hours then incubated at $4{ }^{\circ} \mathrm{C}$ overnight in $5 \%$ skimmed milk powder buffer with VIP receptor primary antibody. The antibody dilution of VIP receptors was 1:200. After washing 
in TTBS three times, the membrane was incubated with anti-rabbit horseradish peroxidase binding immunoglobulin $\mathrm{G}(\mathrm{IgG})$ antibody at $37^{\circ} \mathrm{C}$ for $1 \mathrm{~h}$, and the final dilution was 1:2,000. Antibody binding was observed by adding $6 \mathrm{mg}$ of 3 '-diaminobenzidine tetrachloride (DAB) for $5 \mathrm{~min}$. For negative controls, the same procedure was used, but the primary antibody was omitted. IOD values for Western blots were calculated using Gel-Pro software.

\section{Responses of the clasp and sling strips to Ro25-1553 and PG99-465}

The muscle strips of clasp and sling fibers from the LES were prepared using the method described previously. The silk thread was tied at both ends of the muscle strip, which were then suspended in a bath containing $10 \mathrm{~mL}$ Krebs solution and bubbled with a mixture of $5 \% \mathrm{CO}_{2}$ and $95 \% \mathrm{O}_{2}$ at $37{ }^{\circ} \mathrm{C}$. The isometric force transducer was connected with the upper end of the muscle strips before administration and changes of muscle tension were then recorded by the Medlab system for data analysis. The muscle strips were equilibrated for at least 1 hour and Krebs solution was changed every 20 minutes. Subsequently, each strip was stretched slightly until $200 \mathrm{mg}$ of tension was generated and maintained, and this length of strip was taken as the initial length (L0). The length of the muscle strip was considered optimal when twice the L0.

When the muscle strips reached the optimal initial length, the pharmacological effects of VIP were tested. Thirty minutes after the stabilization of spontaneous tension, Ro25-1553 (selective VPAC2R agonist) was added to the baths with a concentration of $10-9$ to $10-3 \mathrm{~mol} / \mathrm{L}$ and the changes of muscle tension were recorded after the changes stabilized. The Ro25-1553 concentration increased was then 10 times from low to high. Before each administration, Ro25-1553 was administered at the previous concentration to make the muscle strip reach the maximum response. At the end of the process, the bath was thoroughly cleaned, and the tension of the strips was restored to baseline. A concentration-response curve was constructed, and the maximum effect (Emax) was then calculated. Next, PG99-465 (a selective VPAC2R antagonist) was added before adding Ro25-1553 to observe the effect of the antagonist. The concentration of PG99-465 was the same to that of Ro25-1553 that induced the maximum effect on the muscle strips. Our objective at this point was to observe the changes of tension in the muscle strips after administration, and to evaluate its antagonism at the VIP receptors.
In the course of the experiment, tetraodotoxin (TTX) and NG-nitro-L-arginine (L-NOARG) were added to test their effects on the responses of the muscle fibers. We added $10-6 \mathrm{~mol} / \mathrm{L}$ of TTX and $10-5 \mathrm{mmol} / \mathrm{L}$ of L-NOARG to the bath for 10 min respectively, then Ro25-1553 was added and changes in tension was recorded.

\section{Responses of the clasp and sling strips to EFS in the presence of PG99-465}

Before EFS, every muscle strip was prepared using the methods described previously. The muscle strips were placed in the $10-\mathrm{mL}$ jacketed organ baths containing Krebs' solution at $37{ }^{\circ} \mathrm{C}$, with continuous mixed gas of $95 \% \mathrm{O}_{2}$ and $5 \% \mathrm{CO}_{2}$. The lower end of the strip was connected to an L-shaped bracket with a platinum electrode and the upper end was fixed with an isometric force transducer, using the Medlab signal acquisition to record muscle strip tension changes. The muscle strips were stretched to the optimal initial length and were placed in a warm bath for $1 \mathrm{~h}$ in Krebs' solution with continuous mixed gas of $5 \% \mathrm{CO}_{2}$ and $95 \% \mathrm{O}_{2}$. The EFS (single pulse square wave, pulse width $5 \mathrm{~ms}$, voltage $50 \mathrm{~V}$, frequency $1-512 \mathrm{~Hz}$ ) was delivered by a stimulator through two platinum electrodes which were placed in parallel with either side of the tissue strips. After atropine was added, the muscle strips were again subjected to electrical stimulation and the responses of muscle strips to EFS were assessed over a frequency range of 1-512 Hz. Tetrodotoxin (TTX) and PG99-465 (selective VPAC2R antagonist) were then both administrated at a concentration of 10-3 mol/L. The responses of muscle strips stimulated by EFS after $20 \mathrm{~min}$ of administration were then observed.

\section{Statistics analysis}

One-way ANOVA was used to analyze the difference of mRNA and protein expression and the curvefitting facilities of Prism Ver. 2.0 was used to analyze the responses of the LES muscle strips to Ro25-1553, PG99-465, and EFS (GraphPAD Software, USA). The percentage of the baseline value of muscle strip tone relative to the nadir of the response were measured and quantified and the maximum effect (Emax) for each agonist were calculated. Results are reported as mean \pm standard deviation (SD) and $\mathrm{P}<0.05$ was considered to be statistically significant. 
A

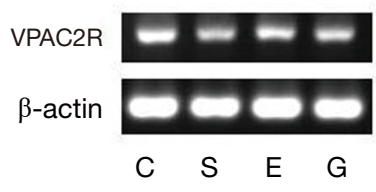

B

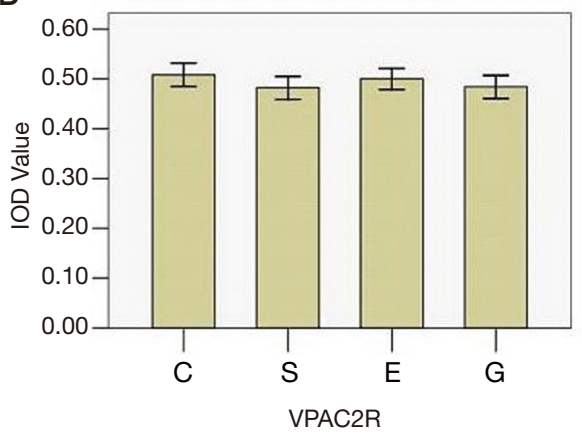

Figure 2 VIP receptor mRNA expression. Gel-Pro gel imaging analysis system was used to analyze and photograph. The integrated optical density (IOD) value of the amplified products was analyzed. VPAC2 receptor mRNA expression values were expressed as the ratios of IOD values for VPAC2 receptor band to corresponding $\beta$-actin bands. VIP receptor subtype expression (VPAC2 receptor) by RT-PCR detection technology in sling and clasp fibers of the lower esophageal sphincter (LES) and circular esophageal and gastric fundal muscle strips. (A) Bands corresponding to VPAC2 receptor mRNA in samples of sling fibers (S), clasp fibers (C) and circular muscle bundles of the esophageal (E) and gastric fundus (G). (B) Comparisons of relative VPAC2 mRNA expression by Reverse transcription polymerase chain reaction (RT-PCR) detection technology in sling fibers (S), clasp fibers (C) and circular muscle bundles of the esophageal (E) and gastric fundus (G). No significant difference in VPAC2 receptor expression was observed between muscle samples $(\mathrm{P}>0.05)$. When $\mathrm{p}$ value is more than 0.05 , the difference is not significant; VIP, vasoactive intestinal peptide. LES, lower esophageal sphincter

\section{Results}

\section{Expression of VIP receptor subtypes in human LES}

\section{VIP receptor mRNA expression}

The ratio of ultraviolet spectrophotometry A260/280 values was between 1.6 and 1.8 for all total RNA samples and $\beta$-actin mRNA bands were uniformly observed at a length of $540 \mathrm{bp}$. VPAC2R transcripts were identified in four muscle samples and VPAC1 and PAC1R mRNA transcripts were not identified in any muscle samples. While all PCR products were the expected size, there was no significant

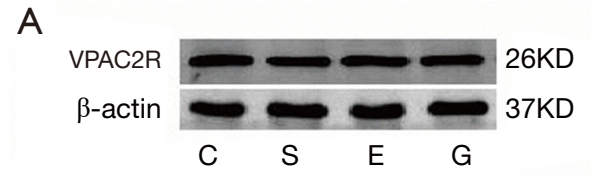

B

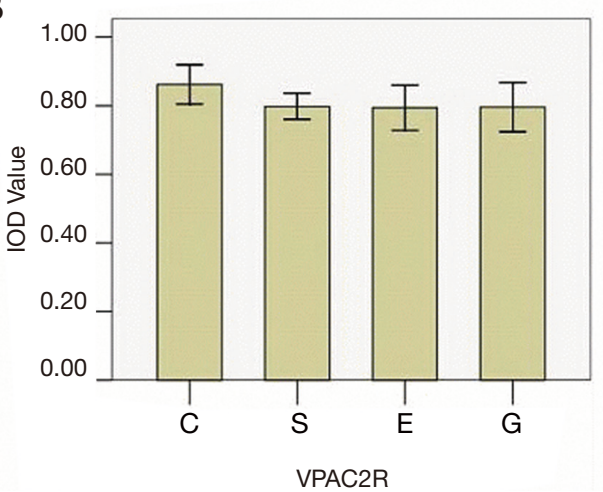

Figure 3 VIP receptor protein expression. VIP receptor subtype protein (VPAC2 receptor) was detected by western blotting of samples from sling fibers and clasp fibers of LES and circular muscle bundles from the esophagus and gastric fundus. (A) Western blot bands corresponding to VPAC2 receptor protein in samples of sling fibers (S), clasp fibers (C) and circular muscle bundles of the esophagus (E) and gastric fundus (G). (B) Integrated optical density (IOD) values. No significant difference in VPAC2 receptor protein levels were observed between muscle samples $(\mathrm{P}>0.05)$. When $\mathrm{P}$ value is more than 0.05 , the difference is not significant; VIP, vasoactive intestinal peptide; LES, lower esophageal sphincter; KD (kilodalton), unit of protein molecular weight.

difference in VPAC2R mRNA expression among the four muscle samples ( $\mathrm{F}=1.530 ; \mathrm{P}=0.245)$ (Figure 2).

\section{VIP receptor protein levels}

VPAC2R, but not VPAC1 or PAC1R, protein expression was detected in muscle samples. There was no significant difference in IOD values among the four muscle samples $(\mathrm{F}=1.543 ; \mathrm{P}=0.242)$ (Figure 3).

\section{Effect of Ro25-1553 and PG99-465 on human LES}

The sling and clasp fibers of the LES produced significant concentration-dependent relaxation following exposure to Ro25-1553 at a concentration of $10-9$ to $10-4 \mathrm{~mol} / \mathrm{L}$. The optimal concentration leading to maximum relaxation was $10-4 \mathrm{~mol} / \mathrm{L}$. The maximum effect (Emax) of the clasp and sling fibers were $(83.6 \pm 0.7) \%$ and $(82.6 \pm 0.9) \%$ respectively, and there was no significant difference in relaxation 


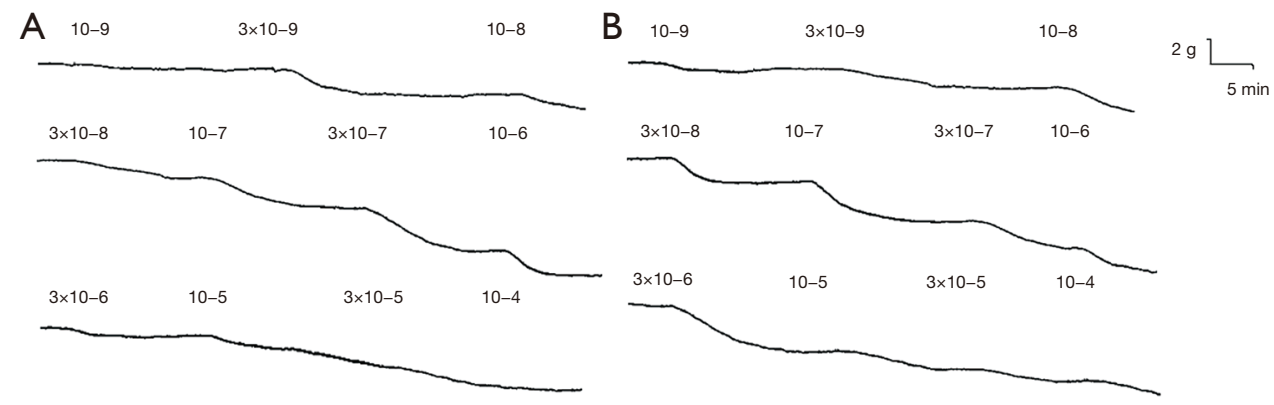

Figure 4 Effect of Ro25-1553 on the clasp and sling fibers. (A) The selective VPAC2R agonist Ro25-1553 induced the concentrationdependent relaxation of clasp fibers from LES at a concentration of (10-9-10-4 mmol/L). (B) The selective VPAC2R agonist Ro25-1553 induced the concentration-dependent relaxation of sling fibers from LES at a concentration of (10-9-10-4 mmol/L). LES, lower esophageal sphincter

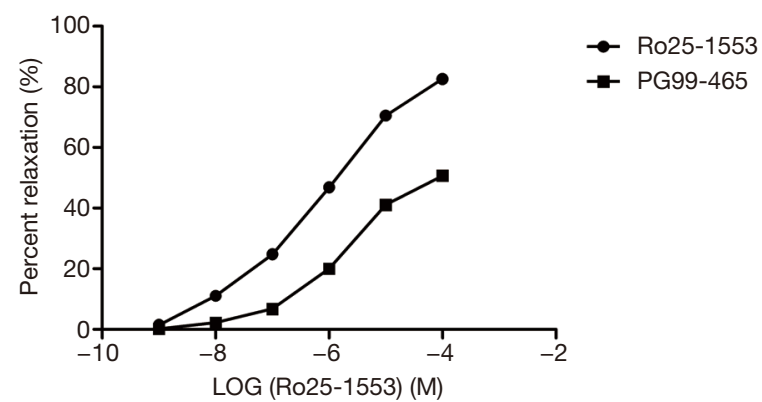

Figure 5 The relaxation of clasp fibers from LES induced by Ro25-1553, before and after the administration of PG99-465. PG99-465 could inhibit the relaxation responses of clasp fibers from the LES induced by Ro25-1553 and there was significant difference in relaxation responses before and after administration $(\mathrm{F}=157, \mathrm{P}<0.01) . \mathrm{M}$, the average; $\mathrm{F}$, the ratio of the two mean squares. When p value is less than 0.05 , the difference is significant; LES, lower esophageal sphincter.

Table 2 Influence of different neurohumoral antagonists on the relaxation of the human lower esophagus sphincter by Ro25-1553

\begin{tabular}{lc}
\hline Reagent & Percent of relaxation (\%) \\
\hline Control & $84.4 \pm 1.4$ \\
Tetrodotoxin $\left(1 \times 10^{-6} \mathrm{M}\right)$ & $83.8 \pm 0.9$ \\
NG-nitro-L-arginine $\left(3 \times 10^{-5} \mathrm{M}\right)$ & $83.3 \pm 0.7$ \\
\hline
\end{tabular}

responses to Ro25-1553 between these two kinds of fibers $(\mathrm{F}=2.22, \mathrm{P}=0.14)$ (Figure 4). $\mathrm{PG} 99-465$ could inhibit the relaxation responses of the LES induced by Ro25-1553 and there was significant difference in relaxation responses before and after administration (Figures 5,6). Both TTX

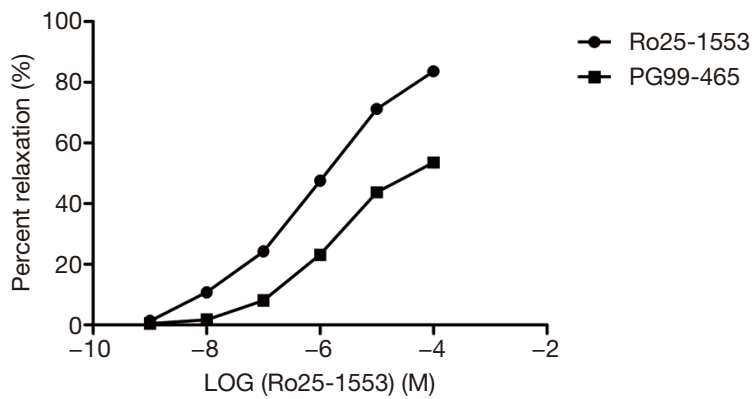

Figure 6 The relaxation of sling fibers from LES induced by Ro25-1553, before and after the administration of PG99-465. PG99-465 could inhibit the relaxation responses of clasp fibers from the LES induced by Ro25-1553 and there was significant difference in relaxation responses before and after administration $(\mathrm{F}=156, \mathrm{P}<0.01) . \mathrm{M}$, the average; $\mathrm{F}$, the ratio of the two mean squares. When p value is less than 0.05 , the difference is significant; LES, lower esophageal sphincter.

and L-NOARG had no significant effect on the relaxation response of the LES induced by RO25-1553, and Emax was similar $(\mathrm{F}=1.40, \mathrm{P}=0.29)$ (Table 2).

\section{Effects of PG99-465 on responses of human LES to EFS}

EFS could induce the sling and clasp fibers of the LES to produce frequency-dependent relaxation and the optimal frequency leading to maximum relaxation was $64 \mathrm{~Hz}$. The maximum relaxation percentage of the sling and clasp fibers were $(20.4 \pm 0.4) \%$ and $(20.1 \pm 0.4) \%$ respectively, and there was no obvious difference in relaxation responses to EFS between the two ( $\mathrm{F}=0.19, \mathrm{P}=0.67$ ) (Figure 7). Both PG99-465 and TTX could inhibit the relaxation responses of LES induced by EFS 
A

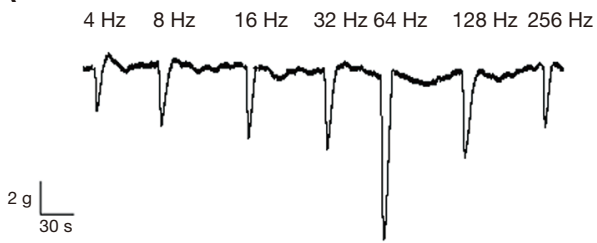

B

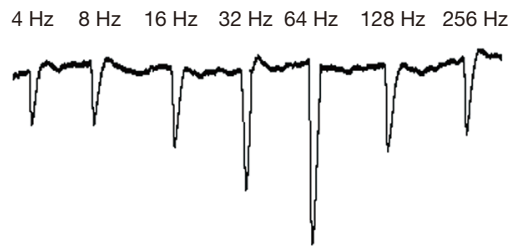

Figure 7 Effect of EFS on the clasp and sling fibers. (A) The EFS induced a frequency-dependent relaxation in the clasp fibers. The optimal frequency causing maximum relaxation was $64 \mathrm{Hertz}(\mathrm{Hz})$. (B) The EFS induced a frequency-dependent relaxation in the sling fibers. The optimal frequency leading to maximum relaxation was $64 \mathrm{Hertz}(\mathrm{Hz})$. EFS, electrical field stimulation.

\section{A}

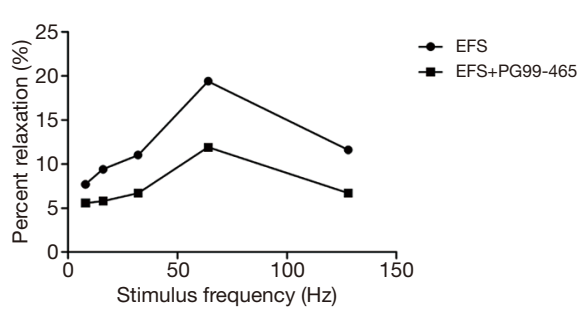

C

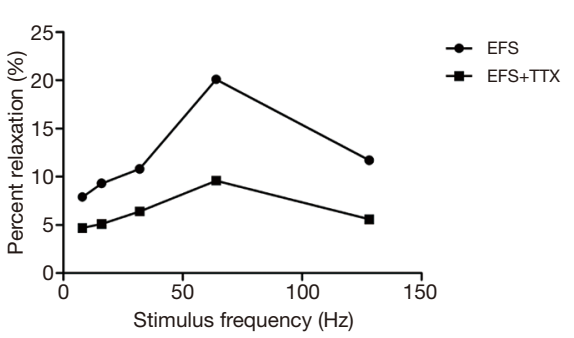

B

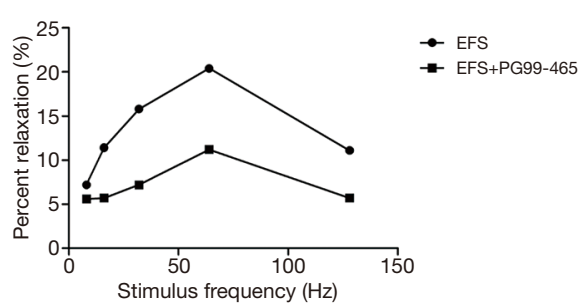

$\mathrm{D}$

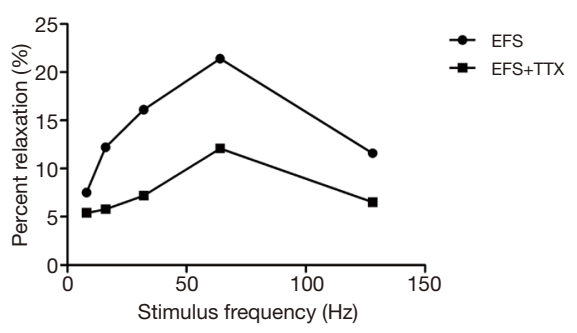

Figure 8 Effect of PG99-465 on the EFS-induced relaxation of clasp fibers. (A) The selective VPAC2R antagonist PG99-465 could inhibit the relaxation responses of clasp fibers from the LES induced by EFS and there were significant differences in relaxation responses before and after administration $(\mathrm{F}=261, \mathrm{P}<0.01)$. Effect of PG99-465 on the EFS-induced relaxation of sling fibers. (B) The selective VPAC2R antagonist PG99-465 could inhibit the relaxation responses of sling fibers from the LES induced by EFS and there were significant differences in relaxation responses before and after administration $(\mathrm{F}=216, \mathrm{P}<0.01)$. Effect of TTX on the EFS-induced relaxation of clasp fibers. (C) Tetrodotoxin (TTX) could inhibit the relaxation responses of clasp fibers from the LES induced by EFS and there were significant differences in relaxation responses before and after administration $(\mathrm{F}=204, \mathrm{P}<0.01)$. Effect of TTX on the EFS-induced relaxation of sling fibers. (D) Tetrodotoxin (TTX) could inhibit the relaxation responses of sling fibers from the LES induced by EFS and there were significant differences in relaxation responses before and after administration $(\mathrm{F}=241, \mathrm{P}<0.01)$. F, the ratio of the two mean squares; When $\mathrm{p}$ value is less than 0.05 , the difference is significant; LES, lower esophageal sphincter; EFS, electrical field stimulation.

and there were significant differences in relaxation responses before and after administration (Figure 8).

\section{Discussion}

Recently, esophageal motility diseases such as achalasia and reflux esophagitis have been found to be associated with dysfunction of the LES. The LES is composed of thickened muscle bundles at the esophagogastric junction and is constituted by half annular clasp and sling fibers at the gastric lesser and greater curvatures, respectively. These two types of muscle fibers maintain the closure of the LES and form its high-pressure zone (HPZ) at the esophagogastric junction $(9,10)$. In addition, higher pressure is observed on the left side of the HPZ. The human LES has a oneway effect, which can separate the stomach with positive pressure from the chest with negative pressure. To prevent the reflux of gastric contents into the esophagus, the LES is 
often kept closed and when it opens, food in the esophagus can enter the stomach. The dysregulation of LES opening leads directly to functional disorders of the LES. Therefore, further studies of the physiological regulatory mechanisms of the LES are required to increase our understanding of the etiology of esophageal motility disorder and inform the development of effective therapies. Previous studies have demonstrated that several receptors, neurotransmitters, and signal transduction pathways are involved in LES regulatory mechanisms (11-14).

The functional regulation of contraction and relaxation of the LES is complex and involves the nervous system, humoral factors, and spontaneous myogenic factors. As a peptide consisting of 28 amino acid types, VIP was first purified from the porcine intestine by Said in $1970(15,16)$ and from human tissue by Carlquist in 1982 (17). VIP was named due to its apparent vasodilatory effects.

The human LES is regulated by non-adrenergic, noncholinergic (NANC) nervous inputs and vagal stimulation. Acetylcholine is the main neurotransmitter of vagal stimulation, and the major NANC neurotransmitters are currently recognised as VIP and nitric oxide (NO). The observation of the expression of VIP and NO in the auerbach plexus of the LES in both humans and mammals supports this view $(18,19)$. VIP can induce decreases in LES pressure and relaxation in many species (20-24). All functions of VIP are mediated by VIP receptors, which belong to the G protein-coupled receptors (GPCRs) family, which predominantly signal via adenylate cyclase activation by the Gs protein.

VIP is one of many structurally linked peptide hormones including PACAP, glucagon, glucagon like peptide, secretory hormone, and GIP. VIP and PACAP work through the PAC1R, VPAC1R and VPAC2R receptors. This family includes not only many hormone related peptide receptors, but also all peptide receptors related to VIP and PACAP structures. VPAC1R and VPAC2R have high selectivity for VIP and PACAP, while PAC1R only has affinity for PACAP. Although VIP and PACAP have different physiological functions, they play an important role in biological rhythm, learning and memory, emotion, and brain injury in the CNS. In this study, we focused on the effect of VIP on the LES only.

It has been confirmed that VIP and VIP agonists and antagonists have considerable pharmacological effects on the LES (23-25). VIP receptors are widely distributed in the human digestive system, so they are closely related to the motility and secretion of the gastrointestinal tract. Recently, there has been increasing focus on the distribution and functional studies of VIP receptor subtypes in gastrointestinal smooth muscle. Ishihara has confirmed the existence of VPAC1R mRNA in the digestive system and brain tissue of rats and Wei et al. identified VPAC2R in the human stomach using a homology-based cloning strategy (26). These findings suggest that VIP receptors are distributed throughout the gastrointestinal tract. However, related research into the expression and regulation of VIP in the human LES has yet to be reported. Our study aimed to clarify the expression and regulation of VIP receptors in the human LES.

Among VIP receptors, VPAC2R has the widest distribution among human tissues and was shown to be expressed at the LES, whereas VPAC1R and PAC1R were not found to be expressed at the LES in our study. The results of this study clearly demonstrate the presence of VPAC2R expression in the human LES and that VPAC2R is also expressed by the circular muscle of the distal esophageal body. We are not aware of any previous studies reporting the expression of VIP receptors at the human LES; therefore, we believe this study provides novel information regarding VIP receptor expression.

Through the measurement of adenylate cyclase activity and immunohistochemical studies, Sigala suggested that both reduced amounts of VIP fibers and reduced VIP receptor activity at the LES may contribute to incomplete relaxation and increased sphincter resting tone in esophageal achalasia. Different antagonists of VIP-induced smooth muscle relaxation were evaluated, including (Lys1, Pro2,5, Arg3,4, Tyr6) VIP, VIP [10-28], VIP [6-28], (D-pCl-Phe6) VIP, and (Ac-Tyr1, D-Phe2) growth hormonereleasing factor-[1-29] amide. The first two antagonists were found to decrease VIP activity but had no effect on EFS-induced LES relaxation $(23,24)$. Combining the above findings with those of our study, we conclude that VIP receptor expression in the human LES suggest that VIP plays an indispensable role in the regulation of LES motor balance. In addition, these results suggest that more studies on specific VIP receptor antagonists are needed to evaluate the effect of VIP in the relaxation of the LES.

This finding seems to imply that the effect of VIP on the reaction of the LES is achieved through VIP receptors. To explore the question of whether VPAC2 receptors have more important pharmacological effect on the LES we used selective VPAC2 receptor agonists and antagonists. EFS could directly activate enteric motor neurons, so it has been widely used in research on the regulatory mechanisms 
of the LES (27). Ro25-1553 (a selective VPAC2 receptor agonist) and EFS induced the concentration (frequency)dependent relaxation of the LES and PG99-465 (selective VPAC2 receptor antagonist) could inhibit the relaxation responses of the LES induced by Ro25-1553 and EFS. This study shows that the VPAC2 receptor participates in the relaxation response of the LES. In summary, the VPAC2 receptor is indispensable for the regulation of the human LES. However, there was no proof that VPAC1 and PAC1 receptors contribute to the function of the LES for lack of their expression.

To examine whether neurogenic components or nitric oxide contributes to the responses, TTX, a $\mathrm{Na}+$ channel blocker and L-NOARG, an inhibitor of nitric oxide synthase, were used in the second half of the study. Neither was shown to be involved in any significant change in the response of any muscle strip to RO25-1553. This suggests that the agonist induced relaxation and the relaxation was due to the direct effect on the receptors of the LES. TTX could inhibit the relaxation responses of the LES induced by EFS. This confirms that the EFS-induced relaxation responses of the LES is neurogenic in origin.

Now it has been proved that VIP receptors are widely distributed in animal digestive tract and play an important role, but the research on the distribution of VIP receptors in human esophagus and the regulation of esophageal function is still in the exploration. This study is the first time to find the expression of VIP receptor mRNA and protein in human LES, which suggests that VIP may play an important role in the regulatory mechanism of LES. The specific mechanism may be that LES releases some neurotransmitters through various nerve conduction pathways, and these neurotransmitters should include VIP which can be specifically antagonized by VPAC2R antagonist (PG99-465). UC A and Farre R found that VIP can relax the lower esophageal sphincter through its receptor. Moreover, VIP receptor antagonists such as (lys1, pro2,5, arg3,4, tyr6) VIP and VIP (10-28) significantly inhibited the relaxation effect of VIP on lower esophageal sphincter $(23,24)$. These results suggest that VIP can induce the relaxation of esophageal smooth muscle through its receptor.

Research shows that the regulatory mechanism of the LES is mainly controlled by different intracellular signal transduction pathways. A variety of receptors and neurotransmitters have realized their regulation of the LES by respective signal transduction pathways. The present study shows that NF- $\mathrm{KB}$ and MAPK signal transduction pathways are two separate signal transduction pathways regulating inflammatory and chemotactic factors generation, while VIP is involved in regulation of the two signal pathways. The CAMP-dependent protein kinase pathway is the mechanism by which VIP plays a physiological role through its receptors $(28,29)$.

We believe this study is the first to identify the effect of VIP receptors on the function of the human LES by using molecular biology and isolated muscle tension technology. Although there are other studies on the physiological and pharmacological effects of VIP receptors on the LES, we suggest that VIP is indispensable in regulating esophageal motility. Further studies are required to identify more specific ligands and signal transduction pathways for each VIP receptor to precisely evaluate the physiological and pharmacological effect of VIP receptors in LES function.

\section{Acknowledgments}

Funding: None.

\section{Footnote}

Reporting Checklist: The authors have completed the MDAR reporting checklist. Available at http://dx.doi.org/10.21037/ apm-21-193

Data Sharing Statement: Available at http://dx.doi. org/10.21037/apm-21-193

Conflicts of Interest: All authors have completed the ICMJE uniform disclosure form (available at http://dx.doi. org/10.21037/apm-21-193). The authors have no conflicts of interest to declare.

Etbical Statement: The authors are accountable for all aspects of the work in ensuring that questions related to the accuracy or integrity of any part of the work are appropriately investigated and resolved. The study was conducted in accordance with the Declaration of Helsinki (as revised in 2013). The study was approved by ethics board of Handan central hospital (NO.: 20200122) and informed consent was taken from all the patients.

Open Access Statement: This is an Open Access article distributed in accordance with the Creative Commons Attribution-NonCommercial-NoDerivs 4.0 International License (CC BY-NC-ND 4.0), which permits the non- 
commercial replication and distribution of the article with the strict proviso that no changes or edits are made and the original work is properly cited (including links to both the formal publication through the relevant DOI and the license). See: https://creativecommons.org/licenses/by-nc-nd/4.0/.

\section{References}

1. Stein HJ, Korn O, Liebermann-Meffert D. What is the relationship between muscular structures and the manometric 3-D image of the lower oesophageal sphincter? In: Giuli R. editor. The Oesophagogastric Junction. Paris: John Libbey, 1998:10-4.

2. Ishihara $\mathrm{T}$, Shigemoto $\mathrm{R}$, Mori $\mathrm{K}$, et al. Functional expression and tissue distribution of a novel receptor for vasoactive intestinal polypeptide. Neuron 1992;8:811-9.

3. Usdin TB, Bonner TI, Mezey E. Two receptors for vasoactive intestinal polypeptide with similar specificity and complementary distributions. Endocrinology 1994;135:2662-80.

4. Ciccarelli E, Svoboda M, De Neef P, et al. Pharmacological properties of two recombinant splice variants of the PACAP type I receptor, transfected and stably expressed in CHO cells. Eur J Pharmacol 1995;288:259-67.

5. Hashimoto H, Ishihara T, Shigemoto R, et al. Molecular cloning and tissue distribution of a receptor for pituitary adenylate cyclaseactivating polypeptide. Neuron 1993;11:333-42.

6. Moller K, Sundler F. Expression of pituitary adenylate cyclase-activating peptide (PACAP) and PACAP type I receptors in the rat adrenal medulla. Regul Pept 1996;63:129-39.

7. Liu JF, Lu HL, Wen SW, et al. Effects of acetylcholine on sling and clasp fibers of the human lower esophageal sphincter. J Gastroenterol Hepatol 2011;26:1309-17.

8. Liu JF, Gao LP, Wen SW, et al. Responses of human sling and clasp fibers to cholecystokinin and gastrin through CCK receptors. J Gastroenterol Hepatol 2008;23:1608-12.

9. Stein HJ, Korn O, Liebermann-Meffert D. Manometric vector volume analysis to assess lower esophageal sphincter function. Ann Chir Gynaecol 1995;84:151-8.

10. Korn O, Stein HJ, Richter TH, et al. Gastroesophageal sphincter: a model. Dis Esophagus 1997;10:105-9.

11. Sigala S, Missale G, Missale C, et al. Different neurotransmitter systems are involved in the development of esophageal achalasia. Life Sci 1995;56:1311-20.

12. Wattchow DA, Furness JB, Costa M, et al. Distributions of neuropeptides in the human esophagus. Gastroenterology
1987;93:1363-71.

13. Goyal RK, Rattan S, Said SI. VIP as a possible neurotransmitter of non-cholinergic non-adrenergic inhibitory neurons. Nature 1980;288:378-80.

14. Uddman R, Alumets J, Edvinsson L, et al. Peptidergic (VIP) innervation of the esophagus. Gastroenterology 1978;75:5-8.

15. Said SI, Mutt V. Polypeptide with broad biological activity: isolation from small intestine. Science 1970;169:1217-8.

16. Mutt V, Said SI. Structure of the Porcine Vasoactive Intestinal Octacos-apeptide. The amino-acid sequence. Use of Kallikrein in its determination. Eur J Biochem 1974;42:581-9.

17. Carlquist M, McDonald TJ, Go VL, et al. Isolation and amino acid composition of human vasoactive intestinal peptide(VIP). Horm Metab Res 1982;14:28-9.

18. Aggestrup S, Uddman R, Jensen SL, et al. Regulatory peptides in the lower esophageal sphincter of man. Regul Pept 1985;10:167-78.

19. Ny L, Alm P, Larsson B, et al. Nitric oxide pathway in cat esophagus: localization of nitric oxide synthase and functional effects. Am J Physiol 1995;268:G59-70.

20. Rattan S, Grady M, Goyal RK. Vasoactive intestinal peptide causes peristaltic contractions in the esophageal body. Life Sci 1982;30:1557-63.

21. Guelrud M, Rossiter A, Souney PF, et al. The effect of vasoactive intestinal polypeptide on the lower esophageal sphincter in achalasia. Gastroenterology 1992;103:377-82.

22. Jury J, Ahmedzadeh N, Daniel EE. A mediator derived from arginine mediates inhibitory junction potentials and relaxations in lower esophageal sphincter: an independent role for vasoactive intestinal peptide. Can J Physiol Pharmacol 1992;70:1182-9.

23. Uc A, Oh ST, Murray JA, et al. Biphasic relaxation of the opossum lower esophageal sphincter: roles of NO, VIP, and CGRP. Am J Physiol 1999;277:G548-54.

24. Farré R, Auli M, Lecea B, et al. Pharmacologic characterization of intrinsic mechanisms controlling tone and relaxation of porcine lo-wer esophageal sphincter. J Pharmacol Exp Ther 2006;316:1238-48.

25. Jun CH, Lee TS, Sohn UD. NO/cyclic GMP pathway mediates the relaxation of feline lower oesophageal sphincter. Auton Autacoid Pharmacol 2003;23:159-66.

26. Wei Y, Mojsov S. Tissue specific expression of different human receptor types for pituitary adenylate cyclaseactivating polypeptide and vasoactive intestinal polypeptide: Implications for their role in human physiology. J Neuroendocrinol 1996;8:811-7. 
27. González AA, Farré R, Clavé P. Different responsiveness of excitatory and inhibitory enteric motor neurons in the human esophagus to electrical field stimulation and to nicotine. Am J Physiol Gastrointest Liver Physiol 2004;287:G299-306.

28. Sorg O, Magistretti PJ. Vasoactive intestinal peptide and noradrenaline exert long-term control on glycogen levels in astrocytes: blockade by protein synthesis inhibition. J.

Cite this article as: Jia T, Zhao N. Expression and function of vasoactive intestinal peptide receptors in human lower esophageal sphincter. Ann Palliat Med 2021;10(3):3067-3077. doi: 10.21037/apm-21-193
Neurosci 1992;12:4923-31.

29. Kim WK, Kan Y, Ganea D, et al. Vasoactive intestinal peptide and pituitary adenylyl cyclase-activating polypeptide inhibit tumor necrosis factor-alpha production in injured spinal cord and in activated microglia via a cAMP-dependent pathway. J Neurosci 2000;20:3622.

(English Language Editor: B. Draper) 